\title{
Relationship between Environment, Smoking Behavior, Education, Poverty, and Prevalence of Stunted Toddler in Indonesia: An Ecological Analysis
}

Agung Dwi Laksono

National Institute of Health Research and Development, The Ministry of Health, The Republic of Indonesia https://orcid.org/0000-0002-9056-0399

Ratna Dwi Wulandari ( $\nabla$ ratna-d-w@fkm.unair.ac.id)

Faculty of Public Health, Universitas Airlangga, Surabaya, Indonesia https://orcid.org/0000-0003-4365-5747

\section{Research Article}

Keywords: stunting, toddler, ecological analysis, sanitation, environment, poverty

Posted Date: November 18th, 2020

DOI: https://doi.org/10.21203/rs.3.rs-110565/v2

License: () (7) This work is licensed under a Creative Commons Attribution 4.0 International License. Read Full License 


\section{Abstract}

Background: The prevalence of stunted toddler in Indonesia is very high. The study was aimed at analyzing ecologically the factors related to the prevalence of stunted toddler in Indonesia.

Methods: Ecological analysis was conducted using secondary data from the Ministry of Health of the Republic of Indonesia report in 2018. Apart from the stunted toddler, 6 other variables analyzed as independent variables were the percentage of households with access to safe drinking water sources, percentage of households with access to proper sanitation, percentage of households that occupy livable houses, percentage of the population who smoke, percentage of poor people, and percentage of the population completing basic education. Data were analyzed using a scatter plot.

Results: The results of the study found that 4 variables (the percentage of household with access to a safe drinking water source, the percentage of household with access to proper sanitation, the percentage of the household that occupy livable houses, and the percentage of the population completing basic education) had a negative relationship with the prevalence of stunted toddlers in Indonesia. This means that the four variables are protective factors for a province to have a high prevalence of stunted toddler. Meanwhile, the percentage of poor people was found to be positively correlated with the prevalence of stunted toddler

Conclusion: It was concluded that the five factors were related to the prevalence of stunted toddler in Indonesia.

\section{Introduction}

According to the World Health Organization, stunting is a chronic nutritional problem characterized by a height $\mathrm{z}$ score for age below minus 2 standard deviations compared to World Health Organization standards. Globally, around 162 million children under five are stunted (World Health Organization, 2015). In 2019, the World Health Organization stated that $21.3 \%$ of all children under 5 years worldwide were stunted (World Health Organization, 2020). Meanwhile, Indonesia is also noted to have a much higher prevalence of stunting, although it has decreased from year to year. Based on data reported by the World Health Organization, Indonesia is among the third countries with the highest prevalence in the South-East Asia Regional. The average prevalence of stunting under five in Indonesia in 2005-2017 was 36.4\% (Data and Information Center of Ministry of Health of The Republic of Indonesia, 2018). The latest data reported by the 2018 Indonesia Basic Health Survey, it is noted that the prevalence of stunted toddlers in Indonesia has an average of $30.6 \%$ (National Institute of Health Research and Development of The Indonesia Ministry of Health, 2019).

The harm caused by stunting does not only apply to individuals but has a wider impact on the quality of a society and country. Stunted toddlers will experience physical growth disorders and cognitive decline (Engidaye et al., 2019). As adults, they will experience decreased productivity and an increased risk of developing degenerative metabolic disorders (Rolfe et al., 2018). On the other hand, another study found that chronic malnutrition (stunting) is detrimental to academic performance among school children (Wolde and Belachew, 2019). We can imagine human resources in a country if the prevalence of stunted toddlers is left without intervention.

Stunting caused by chronic malnutrition is well known. On the other hand, environmental factors were also found to be closely related to the incidence of stunting. It is informed that the availability of proper drinking water and environmental sanitation play a role as a determinant of stunting (Mkhize and Sibanda, 2020). Meanwhile, poverty and poor education cannot be separated as the dominant characteristics of households that have stunted toddlers (Buisman et al., 2019). Based on the background description, the study was aimed at analyzing ecologically the factors related to the prevalence of stunted toddlers in Indonesia.

\section{Materials And Methods}

\section{Study Design}

The study was designed using an ecological analysis approach. Ecological studies focus on comparisons between groups, not individuals. The data analyzed is aggregate data at a certain group or level, which in this study is the provincial level. The variables in an ecological analysis can be aggregate measurements, environmental measurements, or global measurements (Laksono and Kusrini, 2020). The purpose of the ecological studies is to make biological inferences about effects on individual risk or to make ecological inferences about effects on groups (Morgenstern, 1995).

\section{Data Source}

The study was carried out using secondary data from the 2018 Indonesia Basic Health Survey report and the 2018 Indonesia Health Profile report. Both reports are official products of the Ministry of Health of the Republic of Indonesia. The unit of analysis in this study was the province. All provinces in Indonesia were analyzed in this study (34 provinces).

\section{Data Analysis}

The dependent variable in this study was the prevalence of stunted toddler. The prevalence of stunted toddler was the percentage of children aged 0-59 months with indicators of height per age included in the very short and short categories (National Institute of Health Research and Development of The Indonesia Ministry of Health, 2019).

On the other hand, there were 6 independent variables analyzed in this study, namely the percentage of households with access to safe drinking water sources, percentage of households with access to proper sanitation, percentage of households that occupy livable houses, percentage of the population who smoke, percentage of poor people, and percentage of the population completing basic education. 
Households with access to safe drinking water sources are households with access to drinking water obtained from protected drinking water sources including tap water, public hydrant, public taps, water terminals, rainwater storage or springs and protected wells, drilling wells/pumps that have a minimum distance of 10 meters from sewage disposal facilities, waste storage, and garbage collection or disposal sites. Bottled water, water obtained from mobile vendors, and water from wells or unprotected springs are not included in the criteria for access to safe and clean drinking water (National Institute of Health Research and Development of The Indonesia Ministry of Health, 2019).

Households with access to proper sanitation are households that have access to proper sanitation, if the sanitation facilities used to meet health requirements, among others, are equipped with a type of gooseneck or back-shute latrine with a lid and have a septic tank or processing system of wastewater, and is a defecation facility that is used alone or together (National Institute of Health Research and Development of The Indonesia Ministry of Health, 2019).

Households that occupy livable houses are households that have houses that meet the requirements of safety, building, and the minimum adequacy of building area and the health of the occupants. The assessment of livable houses is obtained through composite indicators of seven related indicators, namely access to safe water, access to proper sanitation, sufficient living area (floor area per capita $>7.2 \mathrm{~m}^{2}$ ), type of floor, type of wall, type of roof, and electric lighting (National Institute of Health Research and Development of The Indonesia Ministry of Health, 2019).

Data analysis was carried out in a bivariate manner using a scatter plot. The linear fit line is used as the basis for determining the relationship between the prevalence of stunted toddlers and all independent variables. The entire analysis process utilizes SPSS 21 software.

\section{Ethical Approval}

The analysis in the study was carried out using secondary data from published official reports. For this reason, ethical clearance is not required in the implementation of this study.

\section{Results And Discussion}

Table 1. Descriptive statistics variables of the ecological analysis of the prevalence of stunted toddler in Indonesia

\begin{tabular}{|c|c|c|c|c|c|c|c|}
\hline $\begin{array}{c}\text { Descriptive } \\
\text { Statistics }\end{array}$ & $\begin{array}{c}\text { Prevalence of } \\
\text { stunted } \\
\text { toddler }\end{array}$ & $\begin{array}{c}\text { Percentage of households with } \\
\text { access to safe drinking water } \\
\text { sources } \\
\end{array}$ & $\begin{array}{l}\text { Percentage of households with } \\
\text { access to proper sanitation }\end{array}$ & $\begin{array}{l}\text { Percentage of households } \\
\text { that occupy livable houses }\end{array}$ & $\begin{array}{c}\text { Percentage of the } \\
\text { population who } \\
\text { smoke } \\
\end{array}$ & $\begin{array}{l}\text { Percentage of the population } \\
\text { completing basic education }\end{array}$ & $\begin{array}{c}\text { Percentage } \\
\text { of poor } \\
\text { people } \\
\end{array}$ \\
\hline $\mathrm{N}$ & 34 & 34 & 34 & 34 & 34 & 34 & 34 \\
\hline Mean & 30.2618 & 72.9503 & 69.0738 & 93.9035 & 28.0735 & 76.7474 & 10.6076 \\
\hline Median & 31.2000 & 72.8550 & 68.9450 & 96.0100 & 28.1000 & 77.5550 & 8.9050 \\
\hline \begin{tabular}{|l|} 
Std. \\
Deviation \\
\end{tabular} & 5.30260 & 9.24939 & 11.56479 & 7.91719 & 2.42516 & 6.17287 & 5.70346 \\
\hline Range & 25.10 & 41.53 & 46.83 & 41.23 & 8.50 & 29.29 & 23.88 \\
\hline Minimum & 17.60 & 49.37 & 44.31 & 58.23 & 23.50 & 57.09 & 3.55 \\
\hline Maximum & 42.70 & 90.90 & 91.14 & 99.46 & 32.00 & 86.38 & 27.43 \\
\hline
\end{tabular}

Source: The 2018 Indonesia Basic Health Survey and The 2018 Indonesia Health Profile

Table 1 provides descriptive statistics of the prevalence of stunted toddlers and other variables analyzed in this study. The information presented in Table 2 shows a very high variation between provinces. The lowest prevalence of stunted toddler is $17.60 \%$ (Jakarta Province), while the highest prevalence is $42.70 \%$ (East Nusa Tenggara Province).

Figure 1 shows the map of the prevalence of stunted toddler by the province in Indonesia. Based on this spatial information, it can be seen that the prevalence distribution of stunted toddlers is random. No particular pattern trend was seen. The results of this spatial analysis are different from previous studies that analyzed the 2017 Indonesian Nutritional Status Monitoring. The results of this study inform the trend of a higher prevalence in Eastern Indonesia (Kusrini and Laksono, 2020).

Figure 2 is a scatter plot between the prevalence of stunted toddlers versus the percentage of households with access to a safe drinking water source in Indonesia. It can be seen that the relationship between the two variables shows a negative relationship. This means that the higher the percentage of households with access to a safe drinking water source in a province, the lower the prevalence of stunted toddler in that province. Ecologically, the percentage of households with access to a safe drinking water source is a protective factor for a province to have a high prevalence of stunted toddler.

The results of this ecological analysis are in line with the findings of a previous study in South Africa. The study was conducted by reviewing 27 articles between 2010-2019 that reported on the factors influencing the nutritional status of children under the age of five years. The results of the review show that poor access to water is one of the determinants of stunted toddlers (Mkhize and Sibanda, 2020). Otherwise, previous studies in Indonesia, on a smaller scale, found different information. Source of drinking water was not associated with stunting and anemia among children (Rah et al., 2020).

Figure 3 is a scatter plot between the prevalence of stunted toddlers versus the percentage of households with access to proper sanitation in Indonesia. Ecologically, the relationship between the two variables shows a negative relationship. This means that the higher the percentage of households with access to proper sanitation in a province, the lower the prevalence of stunted toddler in that province. Ecologically, the percentage of households with access to proper sanitation is a protective factor for a province to have a high prevalence of stunted toddlers.

The information from this analysis is in line with previous research in South Africa and Pakistan (Mahmood et al., 2020; Mkhize and Sibanda, 2020). Lack of sanitation facilities is also informed as a determinant of the stunted toddler (Mahmood et al., 2020). Not only applies to toddlers, but improper sanitation is also reported to be one of the factors affecting the nutritional status of adolescent girls in Eastern India (Chattopadhyay et al., 2019).

Page $3 / 19$ 
The negative relationship between the percentage of households with access to the safe drinking water source and the percentage of households with access to proper sanitation with the prevalence of stunted toddler is probably due to disease due to infection. The availability of minimal safe drinking water and poor sanitation triggers infectious diseases such as recurrent diarrhea, which can reduce the nutritional status of toddlers quickly. Moreover, if the infection incident continues to recur (De Vita et al., 2019).

Figure 4 is a scatter plot between the prevalence of stunted toddlers versus the percentage of a household that occupy livable houses in Indonesia. It can be seen that the relationship between the two variables shows a negative relationship. This means that the higher the percentage of the household that occupies livable houses in a province, the lower the prevalence of stunted toddler in that province. Ecologically, the percentage of the household that occupy livable houses is a protective factor for a province to have a high prevalence of stunted toddlers.

The relationship between the percentage of the household that occupies livable houses with the prevalence of stunted toddler is related to the density of home occupants. High occupancy density is often found in slum settlements, especially in urban areas which have limited land area for housing. Previous studies have informed that clusters with problems with the nutritional status of children under five are often found in slum areas or flats (Ahsan et al., 2017; De Vita et al., 2019). The relationship of the percentage of the household that occupies livable houses with the prevalence of stunted toddlers applies in general, not only to the nutritional status of toddlers, including adolescents (Mohanty and Panda, 2020).

Figure 5 is the scatter plot between the prevalence of stunted toddlers versus the percentage of the population who smoke in Indonesia. It can be seen that the two variables do not indicate a relationship. Ecologically, the percentage of the population who smoke in a province does not affect the prevalence of stunted toddler in that province.

Figure 6 is a scatter plot between the prevalence of stunted toddlers versus the percentage of the population completing basic education in Indonesia. It can be seen that the relationship between the two variables shows a negative relationship. This means that the higher the percentage of the population completing basic education in a province, the lower the prevalence of stunted toddler in that province. Ecologically, the percentage of the population completing basic education is a protective factor for a province to have a high prevalence of stunted toddlers.

The findings of this study corroborate previous findings of the positive effect of education on reducing the prevalence of stunted toddlers. The better the level of education, especially the education of mothers of toddlers, the lower the chances of toddlers being stunted (Laksono et al., 2019; Walters et al., 2019; Laksono and Megatsari, 2020). Good parental education also illustrates a better capacity to provide care for toddlers (Nirmala, Februhartanty and Wiradnyani, 2016; Pillai and Maleku, 2019). In general, better education is known as a positive determinant of output performance in the health sector (Ipa et al., 2020; Megatsari et al., 2020; Wulandari and Laksono, 2020b). On the other hand, low levels of education are a barrier to achieving better performance in the health sector (Laksono and Wulandari, 2020; Rohmah et al., 2020).

Finally, the scatter plot between the prevalence of stunted toddlers versus the percentage of poor people in Indonesia can be seen in Figure 7. It can be seen that the relationship between the two variables shows a positive relationship. This means that the higher the percentage of poor people in a province, the higher the prevalence of stunted toddler in that province. Ecologically, the percentage of poor people in a province is a risk factor for a province to have a high prevalence of stunted toddler.

Poverty is a major factor that becomes a barrier to food availability in households. Several previous studies found that low food availability that occurred over the years was identified as the main cause of stunting. This situation has led to previous studies finding more children with problematic nutritional status in families with low socioeconomic levels (Rogawski McQuade et al., 2019). Socioeconomic factors are often found to work together with education as a predictor of performance in the health sector (Wulandari et al., 2019; Wulandari and Laksono, 2020a). Education and socioeconomics have a positive correlation. The better the socioeconomic, the more likely it is to have a better level of education.

The information from the analysis results in this study provides clear guidance for policy-makers who focus on efforts to reduce the prevalence of stunting in Indonesia. A broad, ecological, intervention policy that targets slum areas with the characteristics of its inhabitants who are poor education and poor wealth.

\section{Conclusion}

Based on the results of the study, it could be concluded that 5 variables were proven to be related to the prevalence of stunted toddlers in Indonesia. The five variables were the percentage of households with access to a safe drinking water source, the percentage of households with access to proper sanitation, the percentage of the household that occupy livable houses, the percentage of the population completing basic education, and the percentage of poor people.

\section{Declarations}

\section{Acknowledgments}

The authors are grateful to the National Institute of Health Research and Development of the Republic of Indonesia for providing a report as material for analysis in this study.

\section{Declaration of Conflicting Interests}

The authors declared no potential conflicts of interest concerning the research, authorship, and/or publication of this article.

\section{References}


Ahsan, K. Z. et al. (2017) 'Effects of individual, household and community characteristics on child nutritional status in the slums of urban Bangladesh', Archives of Public Health, 75(1), p. Article number 9. doi: 10.1186/s13690-017-0176-x.

Buisman, L. R. et al. (2019) 'What explains the fall in child stunting in Sub-Saharan Africa?', SSM - Population Health, 8, p. Article number 100384. doi: 10.1016/j.ssmph.2019.100384.

Chattopadhyay, A. et al. (2019) 'WASH practices and its association with nutritional status of adolescent girls in poverty pockets of eastern India', $B M C$ Women's Health, 19(1), p. Article number 89. doi: 10.1186/s12905-019-0787-1.

Data and Information Center of Ministry of Health of The Republic of Indonesia (2018) Situation of Stunted Toddler in Indonesia. Jakarta. Available at: http://www.depkes.go.id/resources/download/pusdatin/infodatin/situasi-balita-pendek-2016.pdf.

Engidaye, G. et al. (2019) 'Under nutrition, maternal anemia and household food insecurity are risk factors of anemia among preschool aged children in Menz Gera Midir district, Eastern Amhara, Ethiopia: A community based cross-sectional study', BMC Public Health, 19(1), p. Article number 968. doi:

$10.1186 / \mathrm{s} 12889-019-7293-0$.

Ipa, M. et al. (2020) 'Variation of preventive practices and its association with malaria infection in eastern Indonesia: Findings from community-based survey', PLOS ONE, 15(5), p. e0232909. doi: 10.1371/journal.pone.0232909.

Kusrini, I. and Laksono, A. D. (2020) 'Regional disparities of stunted toddler in indonesia', Indian Journal of Forensic Medicine and Toxicology, 14(3), pp. $1685-1691$.

Laksono, A. D. et al. (2019) 'Characteristics of mother as predictors of stunting in toddler', Pakistan Journal of Nutrition, 18(12), pp. 1101-1106. doi: 10.3923/pjn.2019.1101.1106.

Laksono, A. D. and Kusrini, I. (2020) 'Ecological Analysis of Stunted Toddler in Indonesia', Indian Journal of Forensic Medicine \& Toxicology, 14(3), pp. 16851691.

Laksono, A. D. and Megatsari, H. (2020) 'Determinants of Stunted Toddler in East Java: Analysis of the 2017 Nutrition Status Monitoring Data', Amerta Nutrition, 4(2), pp. 109-115. doi: 10.2473/amnt.v4i2.2020.109-115.

Laksono, A. D. and Wulandari, R. D. (2020) 'The Barrier to Maternity Care in Rural Indonesia', J Public Health (Berl.): From Theory to Practice, p. Online First. doi: 10.1007/s10389-020-01274-3.

Mahmood, T. et al. (2020) 'Why under five children are stunted in Pakistan? A multilevel analysis of Punjab Multiple indicator Cluster Survey (MICS-2014)', BMC Public Health, 20(1), p. Article number 952. doi: 10.1186/s12889-020-09110-9.

Megatsari, H. et al. (2020) 'The community psychosocial burden during the COVID-19 pandemic in Indonesia', Heliyon, 6(10), p. Article number e05136. doi: 10.1016/j.heliyon.2020.e05136.

Mkhize, M. and Sibanda, M. (2020) 'A review of selected studies on the factors associated with the nutrition status of children under the age of five years in South Africa', International Journal of Environmental Research and Public Health, 17(21), pp. 1-26. doi: 10.3390/ijerph17217973.

Mohanty, S. and Panda, M. (2020) 'Study of epidemiological determinants of undernutrition among adolescent girls in urban slums of Berhampur, Odisha: A cross-sectional study', International Journal of Adolescent Medicine and Health, In press, p. Article number 20190208. doi: 10.1515/ijamh-2019-0208.

Morgenstern, H. (1995) 'Ecologic Studies in Epidemiology: Concepts, Principles, and Methods', Annual Review of Public Health, 16, pp. 61-81. doi: 10.1146/annurev.pu.16.050195.000425.

National Institute of Health Research and Development of The Indonesia Ministry of Health (2019) The 2018 Indonesia Basic Health Survey (Riskesdas): National Report. Jakarta. Available at:

http://labmandat.litbang.depkes.go.id/images/download/laporan/RKD/2018/Laporan\%7B\%5C_\%7DNasional\%7B\%5C_\%7DRKD2018\%7B\%5C_\%7DFINAL.pdf

Nirmala, I. R., Februhartanty, J. and Wiradnyani, L. A. A. (2016) 'Maternal attributes are positively associated with feeding practices of children aged 2-5 years in West Java, Indonesia', Malaysian Journal of Nutrition, 22(2), pp. 191-205.

Pillai, V. K. and Maleku, A. (2019) 'Women's education and child stunting reduction in India', Journal of Sociology and Social Welfare, 4(3), pp. 111-130.

Rah, J. H. et al. (2020) 'Improved sanitation is associated with reduced child stunting amongst Indonesian children under 3 years of age', Maternal and Child Nutrition, 16(S2), p. Article number e12741. doi: 10.1111/mcn.12741.

Rogawski McQuade, E. T. et al. (2019) 'Seasonal Food Insecurity in Haydom, Tanzania, Is Associated with Low Birthweight and Acute Malnutrition: Results from the MAL-ED Study', The American Journal of Tropical Medicine and Hygiene, 100(3), pp. 681-687. doi: 10.4269/ajtmh.18-0547.

Rohmah, N. et al. (2020) 'Determinants of teenage pregnancy in Indonesia', Indian Journal of Forensic Medicine and Toxicology, 14(3), pp. 2080-2085. 
Rolfe, E. D. L. et al. (2018) 'Associations of stunting in early childhood with cardiometabolic risk factors in adulthood', PLoS ONE, 13(4), p. Article number e0192196. doi: 10.1371/journal.pone.0192196.

De Vita, M. V. et al. (2019) 'Malnutrition, morbidity and infection in the informal settlements of Nairobi, Kenya: An epidemiological study', Italian Journal of Pediatrics, 45(1), p. Article number 12. doi: 10.1186/s13052-019-0607-0.

Walters, C. N. et al. (2019) 'Maternal determinants of optimal breastfeeding and complementary feeding and their association with child undernutrition in Malawi (2015-2016)', BMC Public Health, 19(1), p. Article number 1503. doi: 10.1186/s12889-019-7877-8.

Wolde, T. and Belachew, T. (2019) 'Chronic undernutrition (stunting) is detrimental to academic performance among primary schools of adolescent children: A randomized cross sectional survey in Southern Ethiopia', BMC Research Notes, 12(1), p. Article number 142. doi: 10.1186/s13104-019-4160-0.

World Health Organization (2015) 'World Health Assembly Global Nutrition Targets 2025. Stunting Policy Brief.'

World Health Organization (2020) Child stunting. Available at: https://www.who.int/gho/child-malnutrition/stunting/en/ (Accessed: 18 November 2020).

Wulandari, R. D. et al. (2019) 'Socioeconomic Disparities in Hospital Utilization among Elderly People in Indonesia', Indian Journal of Public Health Research and Development. Surabaya, 10(11), pp. 1800-1804. doi: 10.5958/0976-5506.2019.03885.3.

Wulandari, R. D. and Laksono, A. D. (2020a) 'Determinants of knowledge of pregnancy danger signs in Indonesia', PLoS ONE, 15(5), p. Article number e0232550. doi: 10.1371/journal.pone.0232550.

Wulandari, R. D. and Laksono, A. D. (2020b) 'Education as predictor of the knowledge of pregnancy danger signs in Rural Indonesia', International Journal of Innovation, Creativity and Change, 13(1), pp. 1037-1051.

\section{Figures}

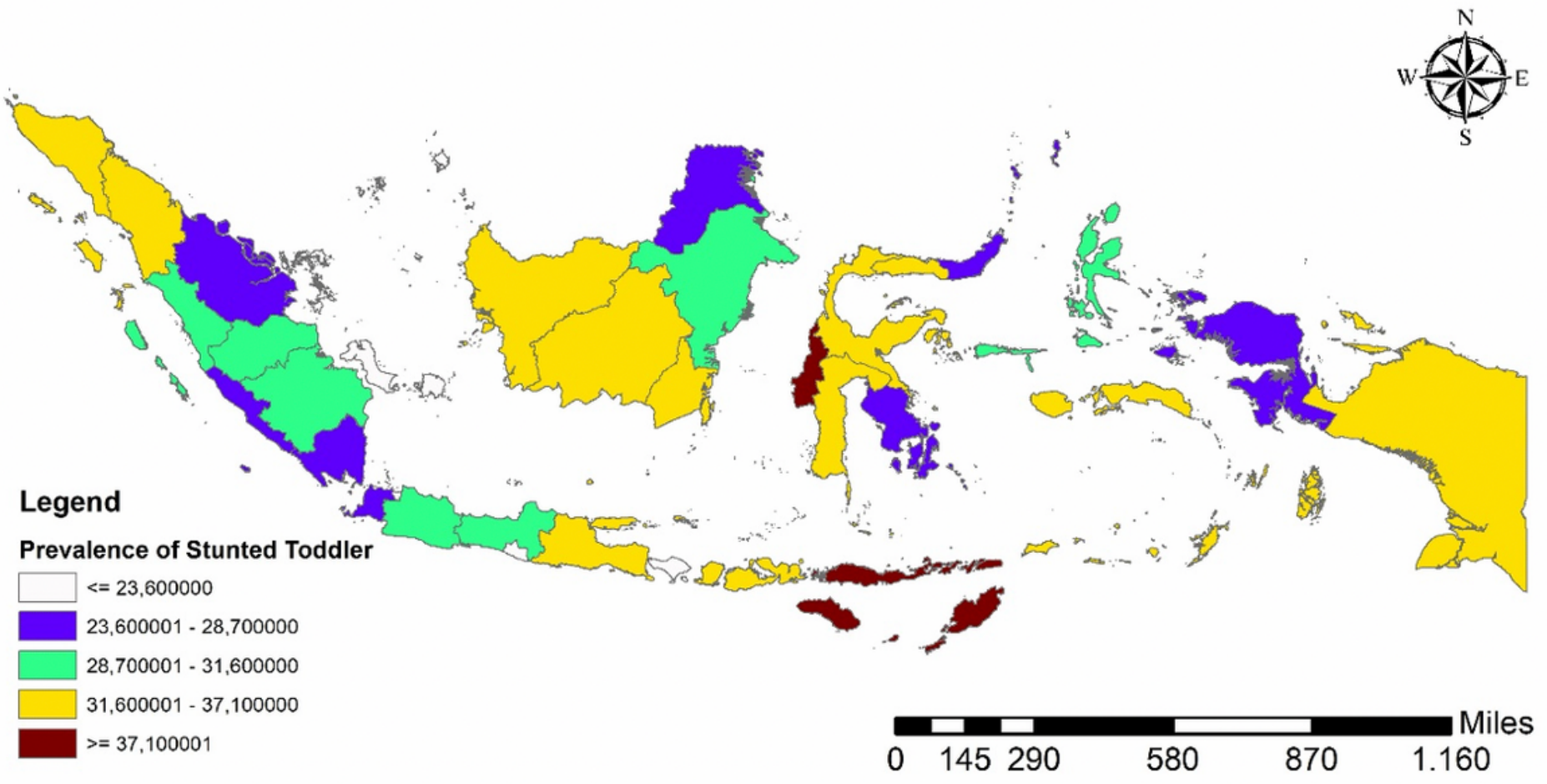

\section{Figure 1}

Map of the Prevalence of Stunted Toddler by Province in Indonesia, 2018 Source: The 2018 Indonesia Basic Health Survey and The 2018 Indonesia Health Profile. Note: The designations employed and the presentation of the material on this map do not imply the expression of any opinion whatsoever on the part of Research Square concerning the legal status of any country, territory, city or area or of its authorities, or concerning the delimitation of its frontiers or boundaries. This map has been provided by the authors. 


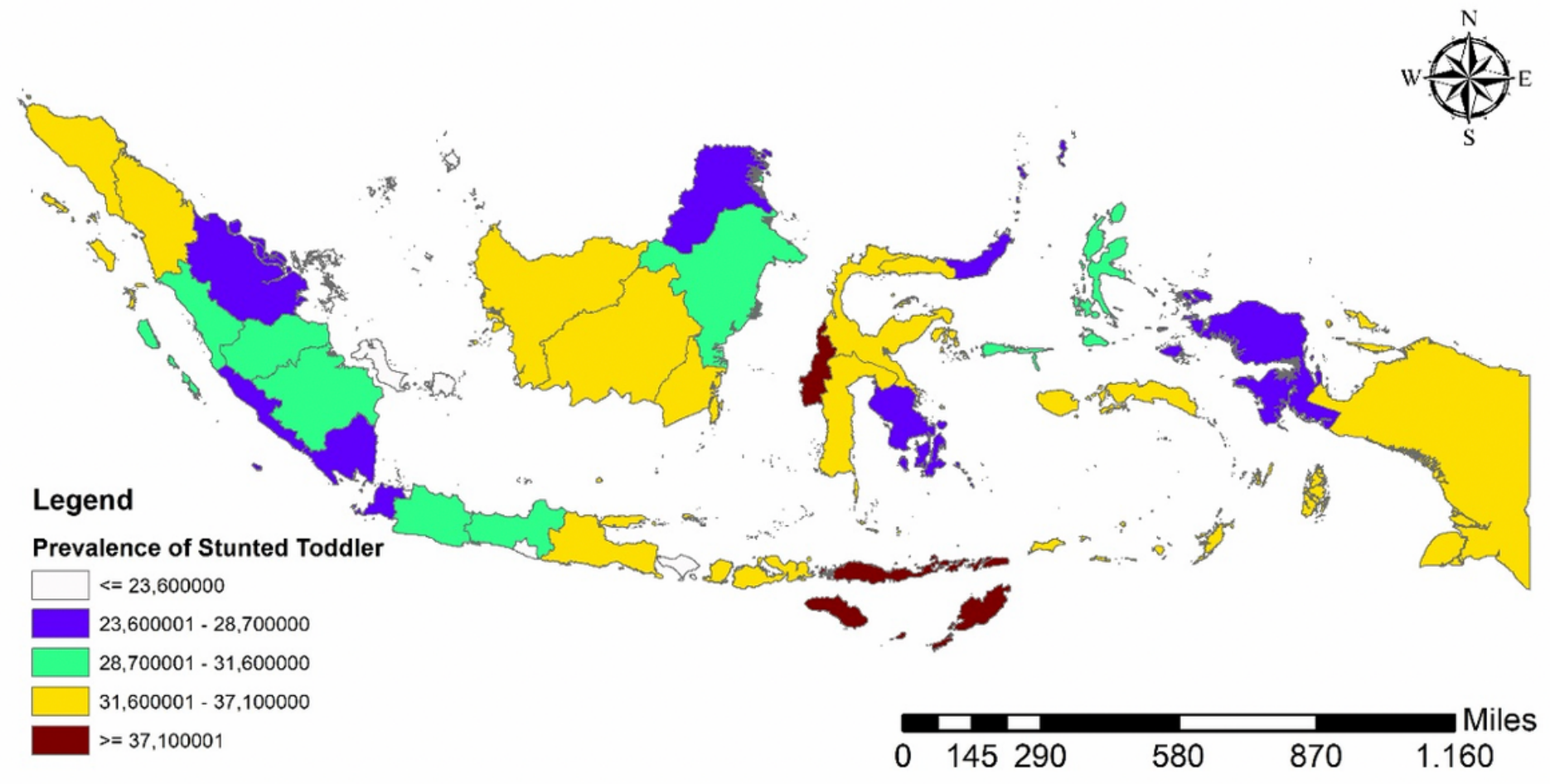

\section{Figure 1}

Map of the Prevalence of Stunted Toddler by Province in Indonesia, 2018 Source: The 2018 Indonesia Basic Health Survey and The 2018 Indonesia Health Profile. Note: The designations employed and the presentation of the material on this map do not imply the expression of any opinion whatsoever on the part of Research Square concerning the legal status of any country, territory, city or area or of its authorities, or concerning the delimitation of its frontiers or boundaries. This map has been provided by the authors. 


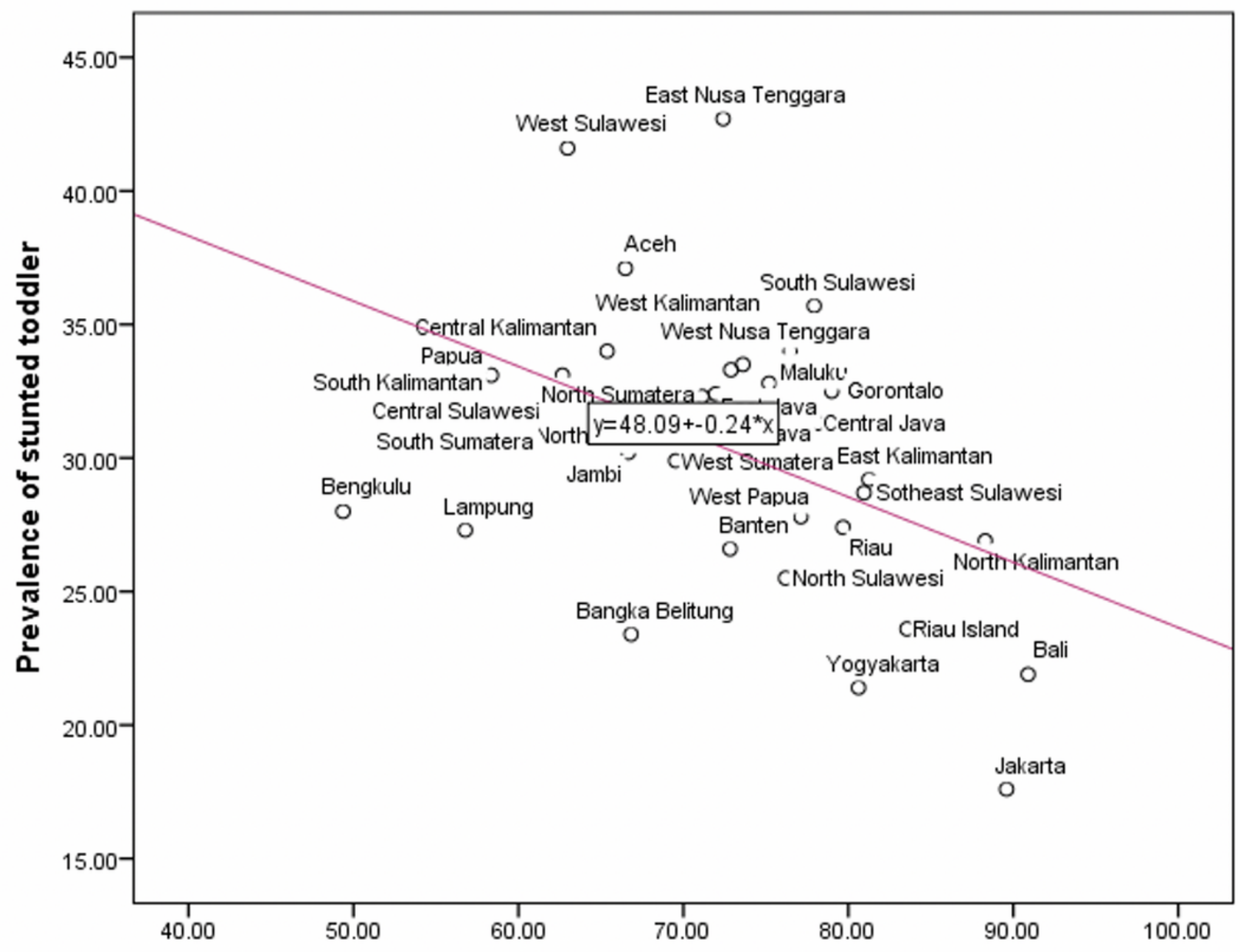

Percentage of households with access to safe drinking water sources

Figure 2

Scatter Plot of the Prevalence of Stunted Toddler and the Percentage of Household with Access to Safe Drinking Water Source in Indonesia, 2018 Source: The 2018 Indonesia Basic Health Survey and The 2018 Indonesia Health Profile 


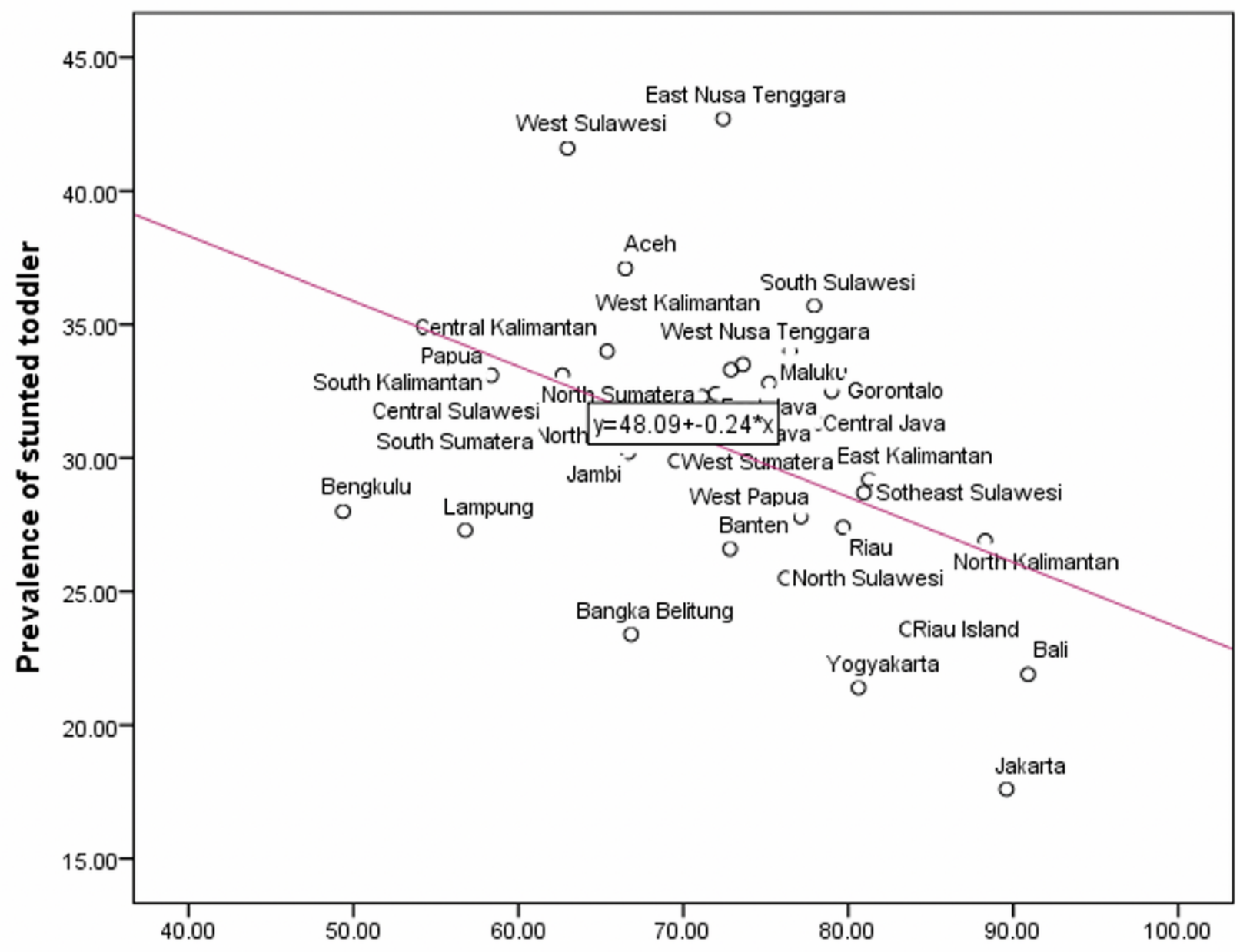

Percentage of households with access to safe drinking water sources

Figure 2

Scatter Plot of the Prevalence of Stunted Toddler and the Percentage of Household with Access to Safe Drinking Water Source in Indonesia, 2018 Source: The 2018 Indonesia Basic Health Survey and The 2018 Indonesia Health Profile 


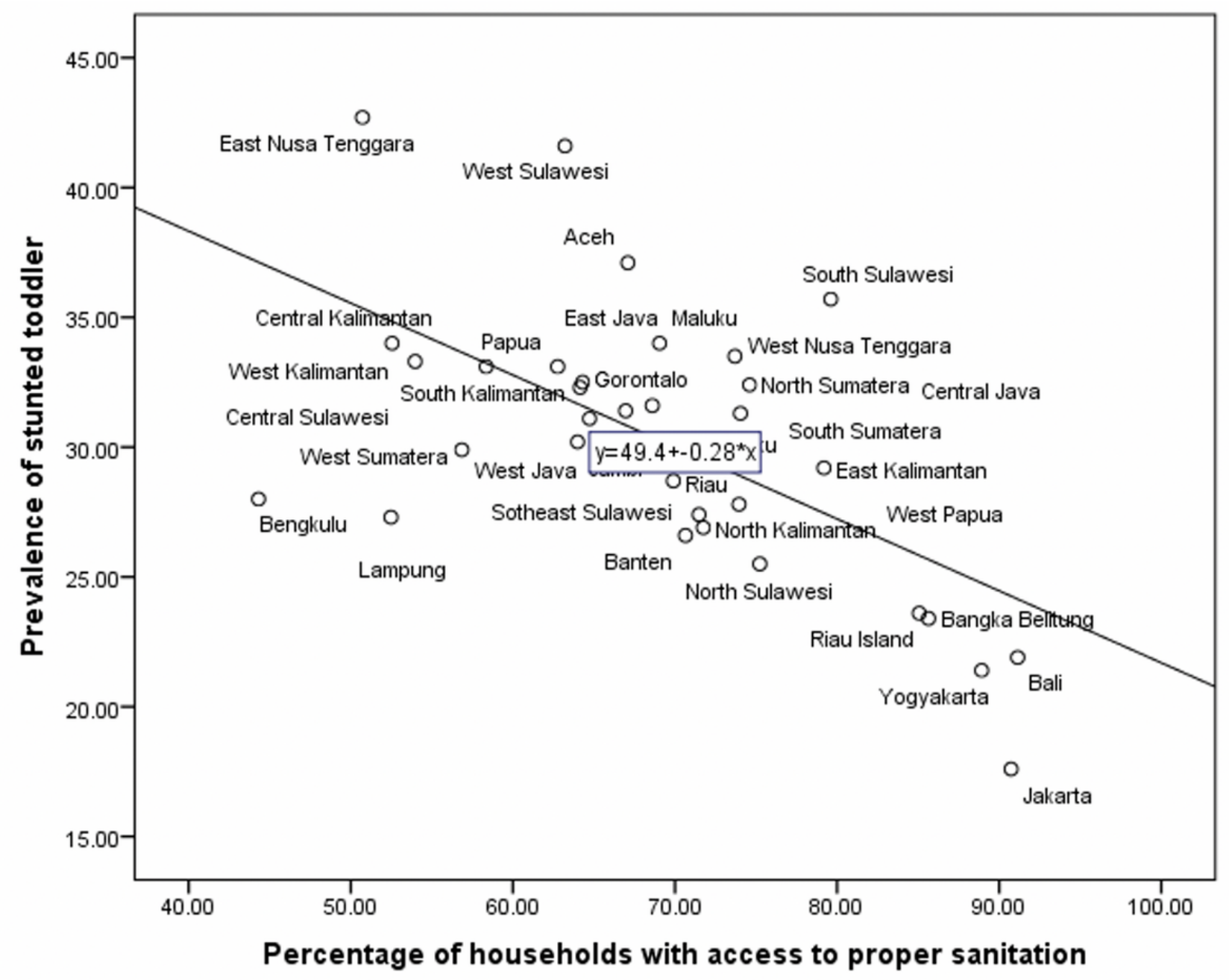

Figure 3

Scatter Plot of the Prevalence of Stunted Toddler and the Percentage of Household with Access to Proper Sanitation in Indonesia, 2018 Source: The 2018 Indonesia Basic Health Survey and The 2018 Indonesia Health Profile 


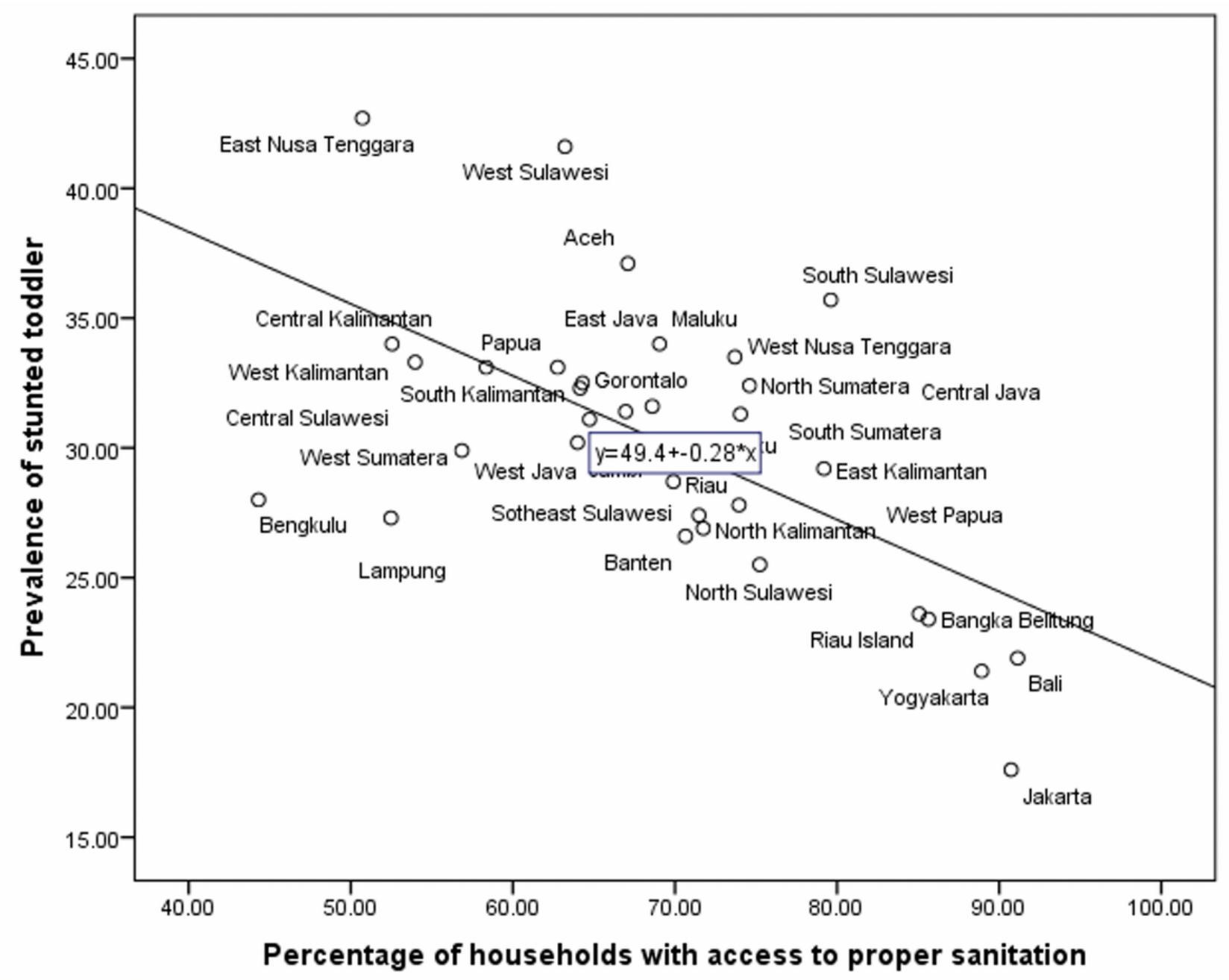

Figure 3

Scatter Plot of the Prevalence of Stunted Toddler and the Percentage of Household with Access to Proper Sanitation in Indonesia, 2018 Source: The 2018 Indonesia Basic Health Survey and The 2018 Indonesia Health Profile 


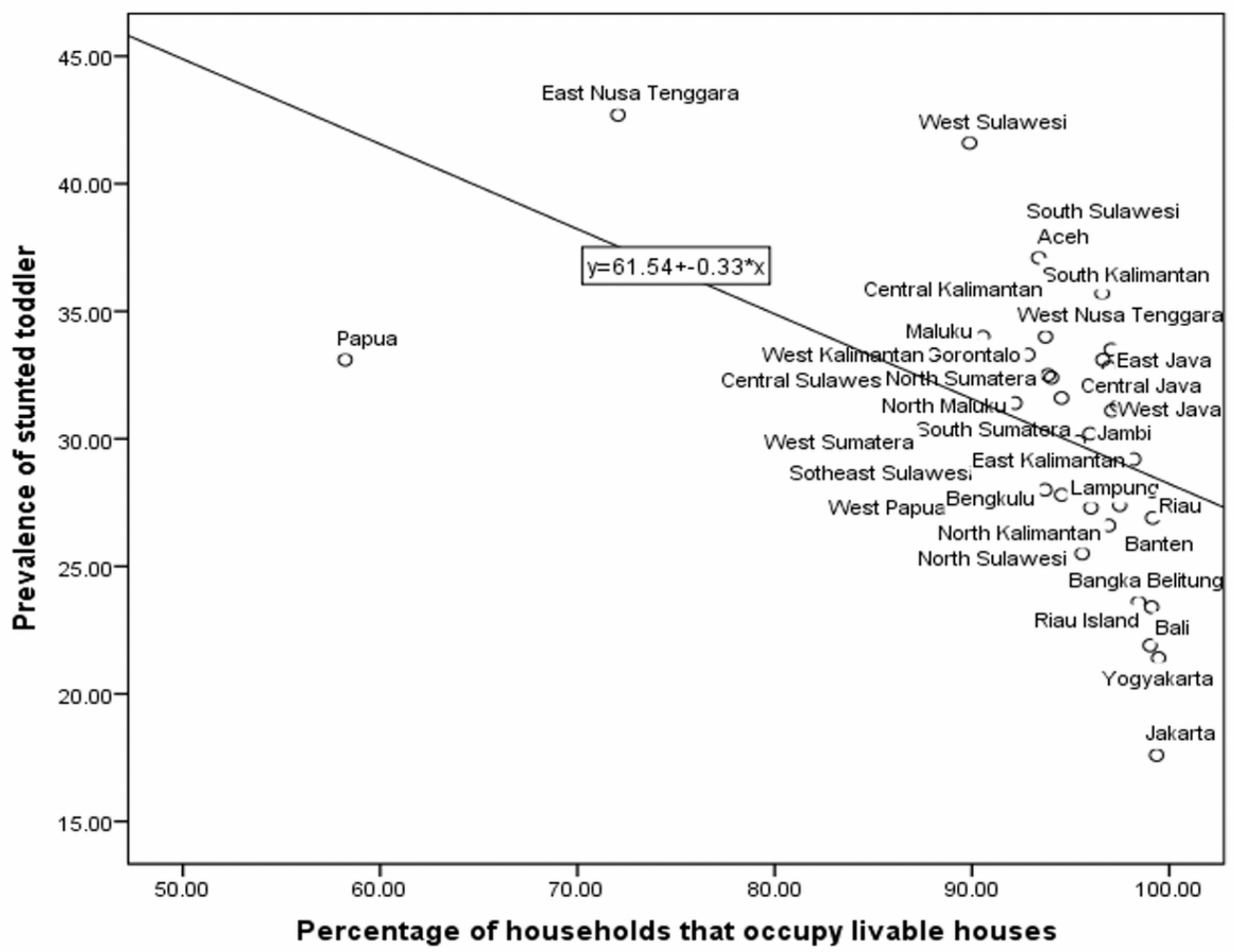

Figure 4

Scatter Plot of the Prevalence of Stunted Toddler and the Percentage of Household that Occupy Livable Houses in Indonesia, 2018 Source: The 2018 Indonesia Basic Health Survey and The 2018 Indonesia Health Profile 


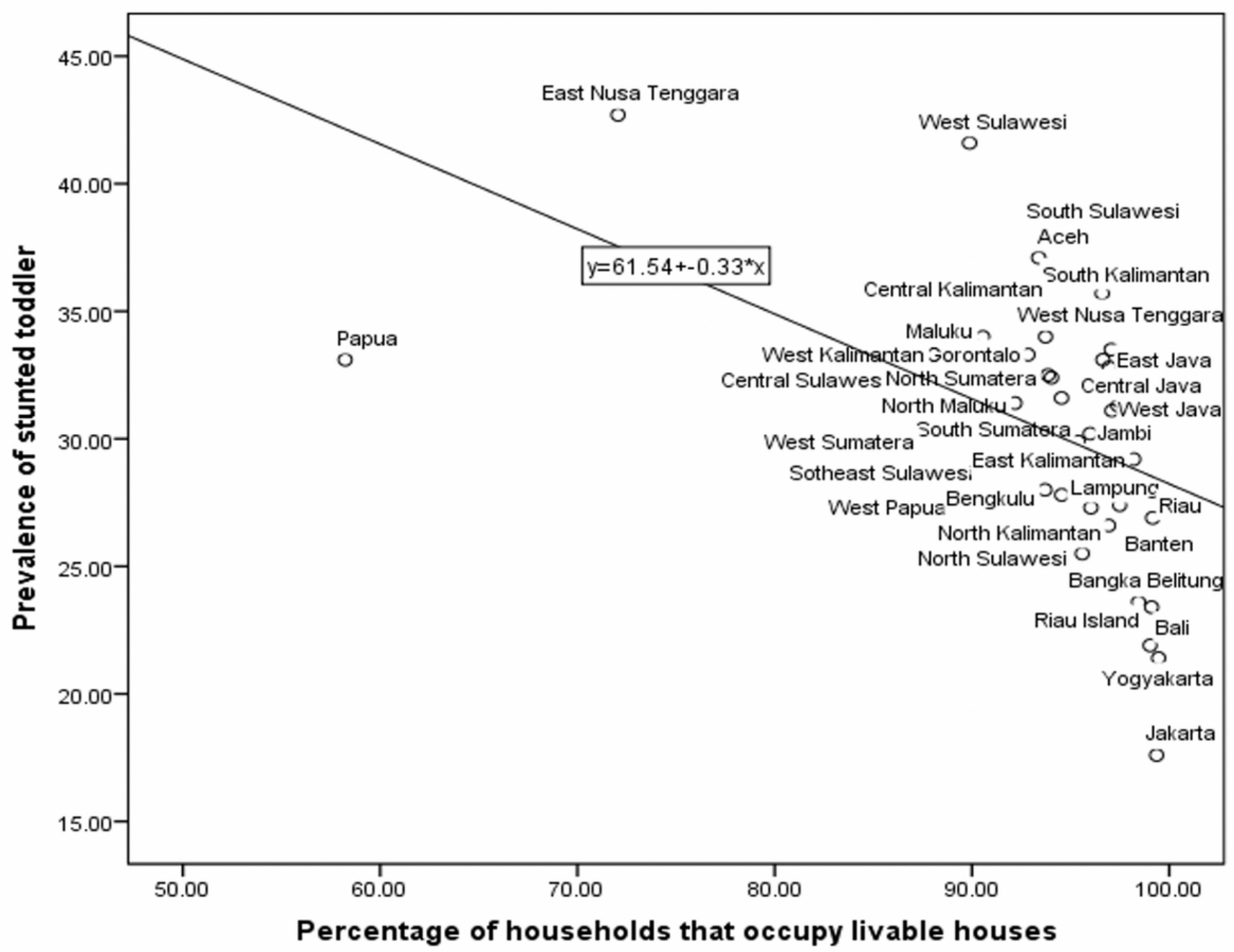

Figure 4

Scatter Plot of the Prevalence of Stunted Toddler and the Percentage of Household that Occupy Livable Houses in Indonesia, 2018 Source: The 2018 Indonesia Basic Health Survey and The 2018 Indonesia Health Profile 


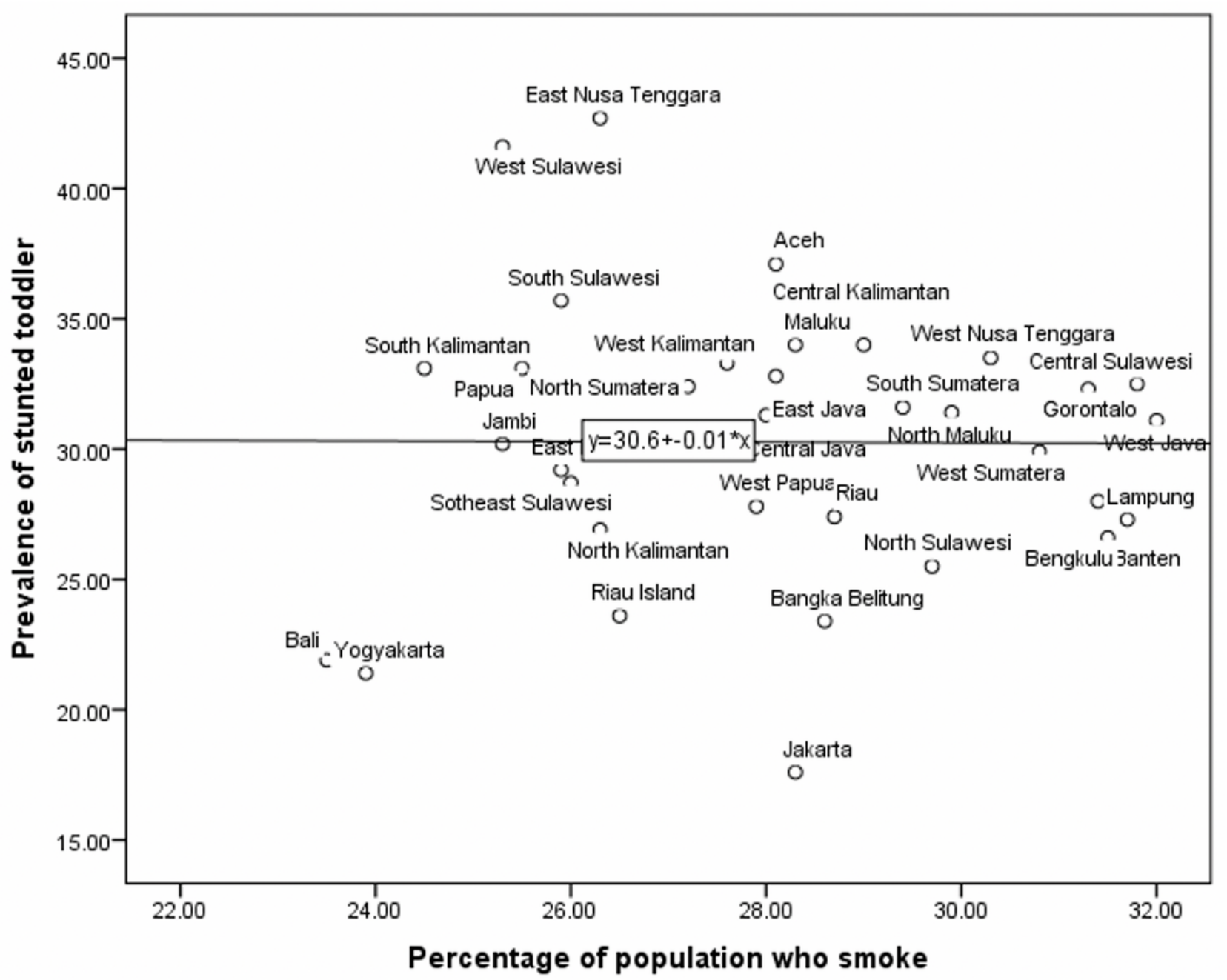

Figure 5

Scatter Plot of the Prevalence of Stunted Toddler and the Percentage of Population who Smoke in Indonesia, 2018 Source: The 2018 Indonesia Basic Health Survey and The 2018 Indonesia Health Profile 


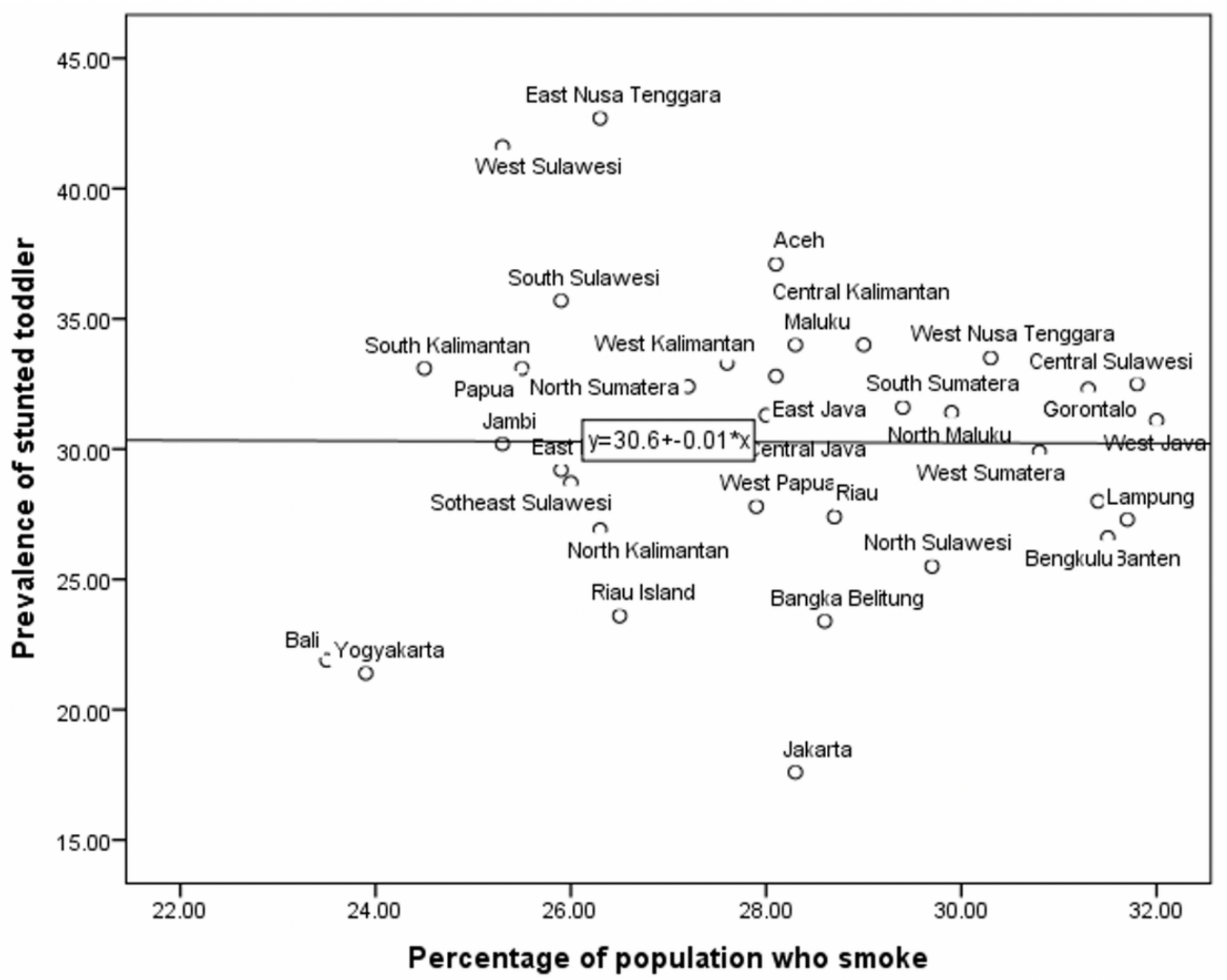

Figure 5

Scatter Plot of the Prevalence of Stunted Toddler and the Percentage of Population who Smoke in Indonesia, 2018 Source: The 2018 Indonesia Basic Health Survey and The 2018 Indonesia Health Profile 


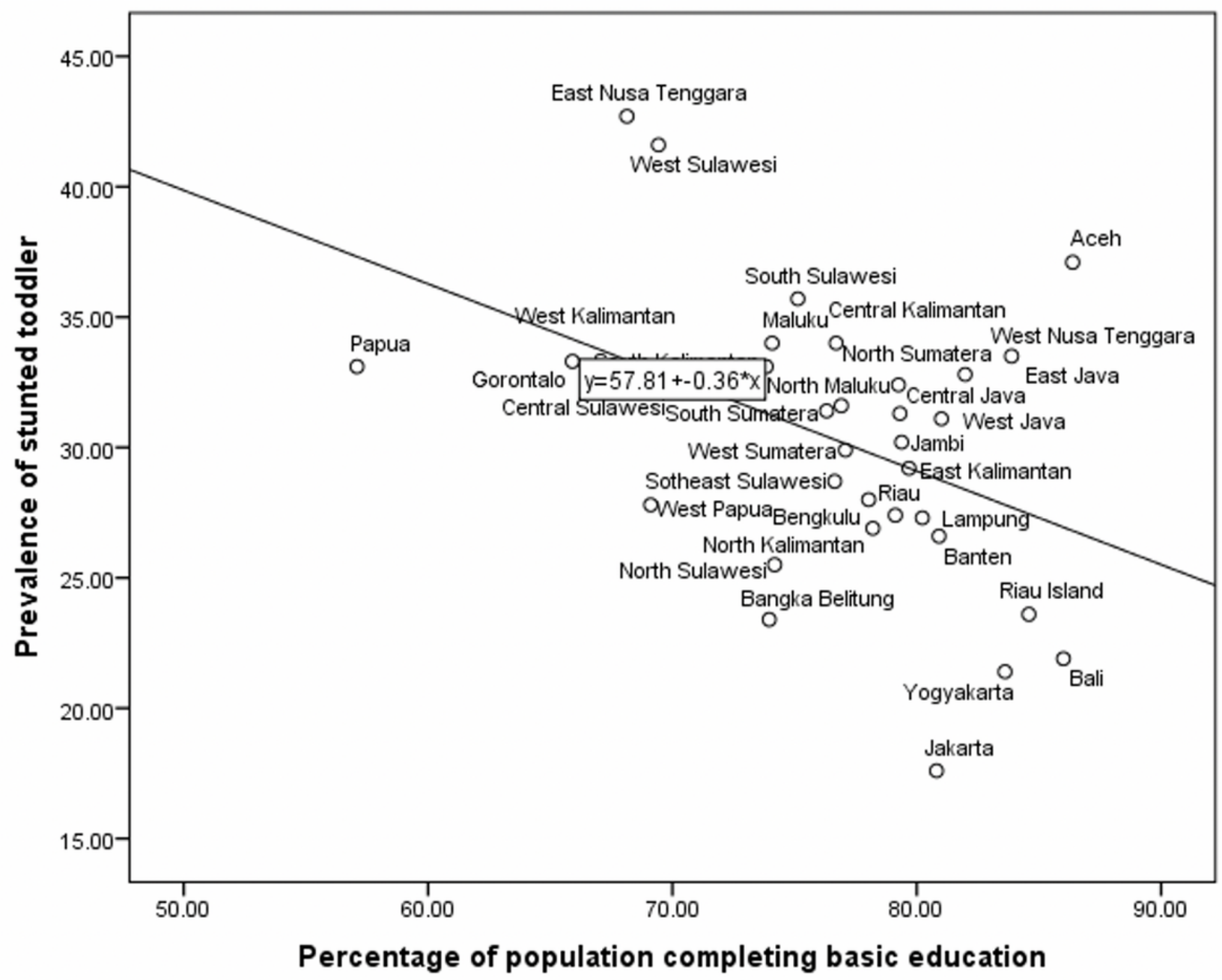

Figure 6

Scatter Plot of the Prevalence of Stunted Toddler and the Percentage of Population Completing Basic Education in Indonesia, 2018 Source: The 2018 Indonesia Basic Health Survey and The 2018 Indonesia Health Profile 


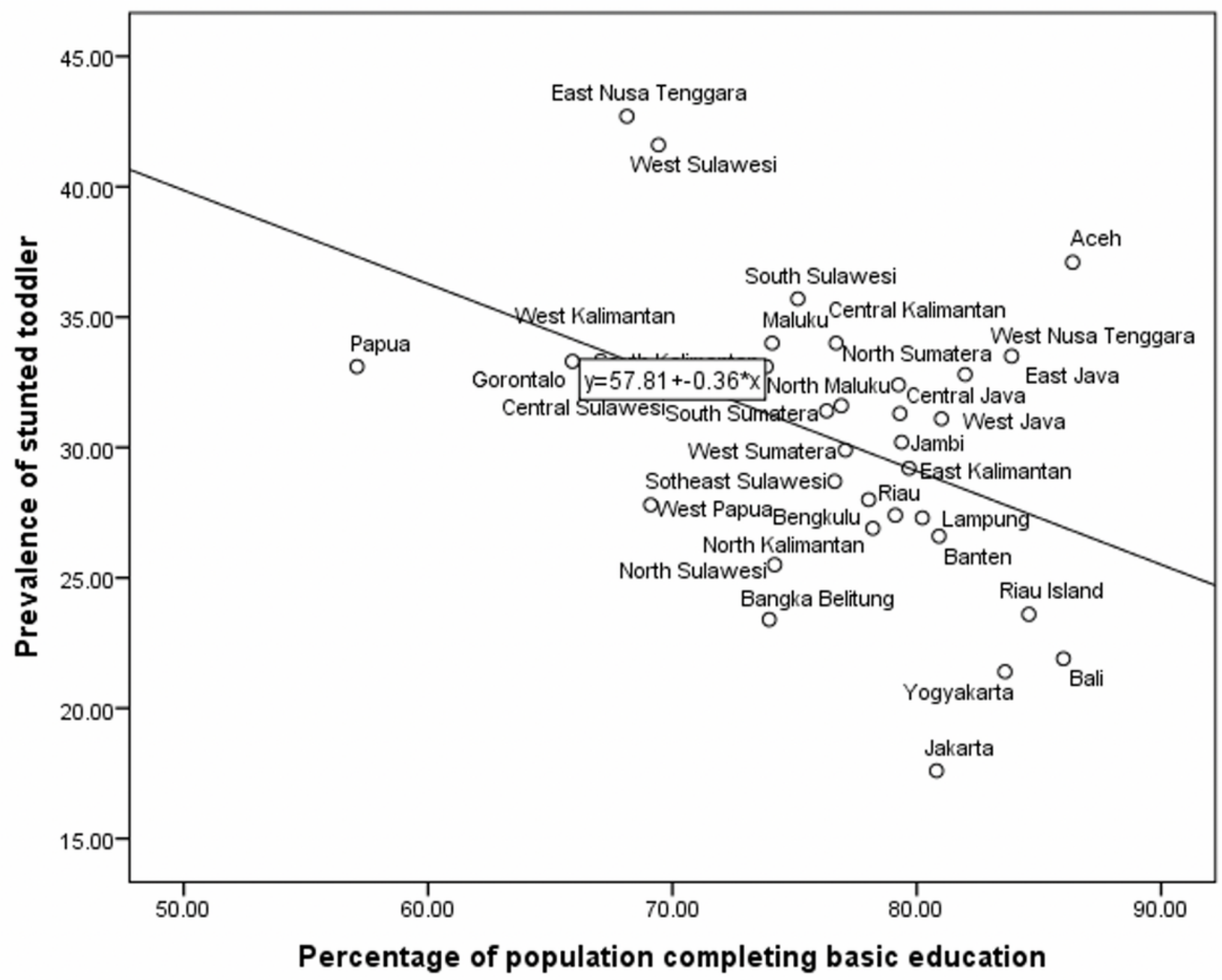

Figure 6

Scatter Plot of the Prevalence of Stunted Toddler and the Percentage of Population Completing Basic Education in Indonesia, 2018 Source: The 2018 Indonesia Basic Health Survey and The 2018 Indonesia Health Profile 


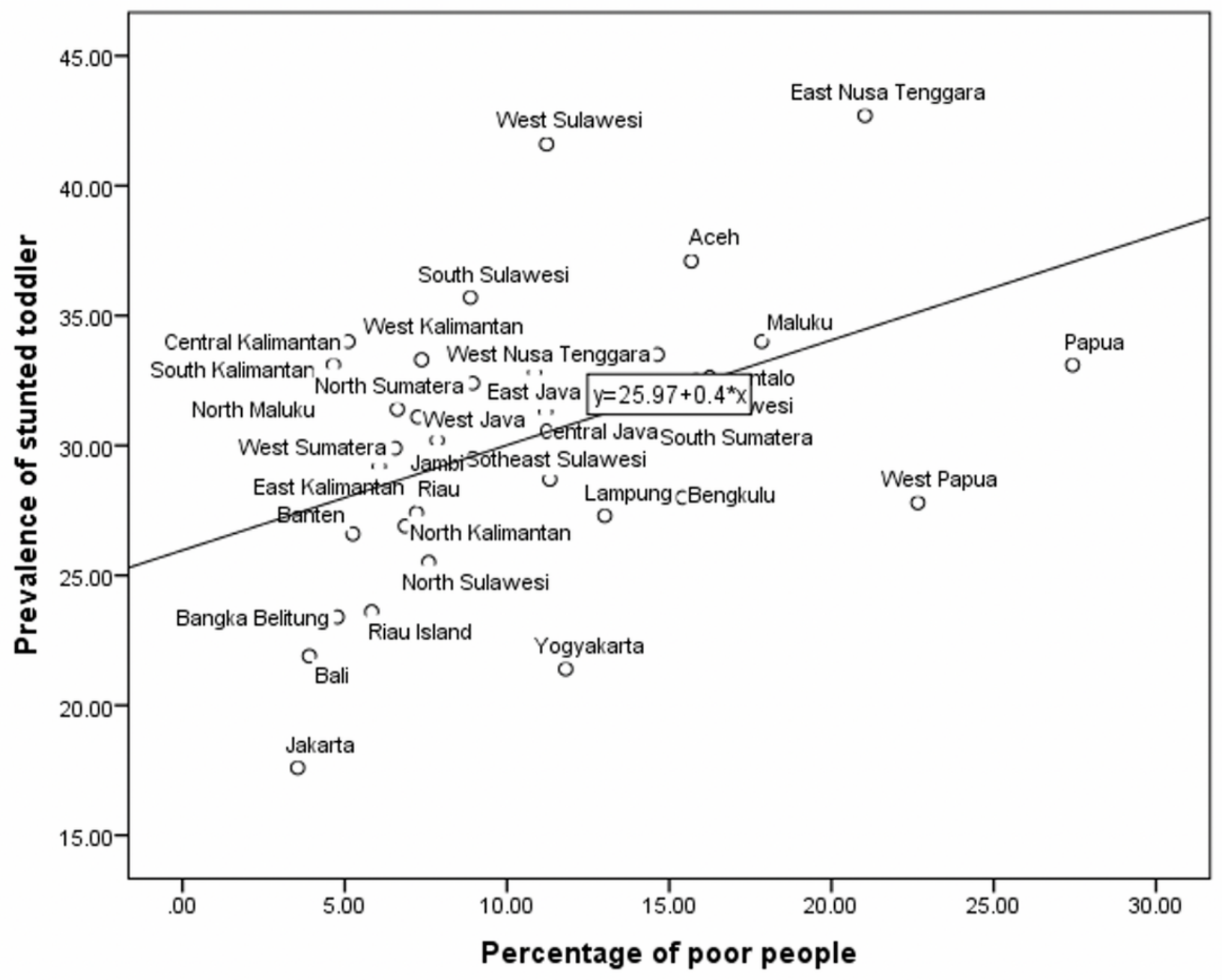

Figure 7

Scatter Plot of the Prevalence of Stunted Toddler and the Percentage of Poor People in Indonesia, 2018 Source: The 2018 Indonesia Basic Health Survey and The 2018 Indonesia Health Profile 


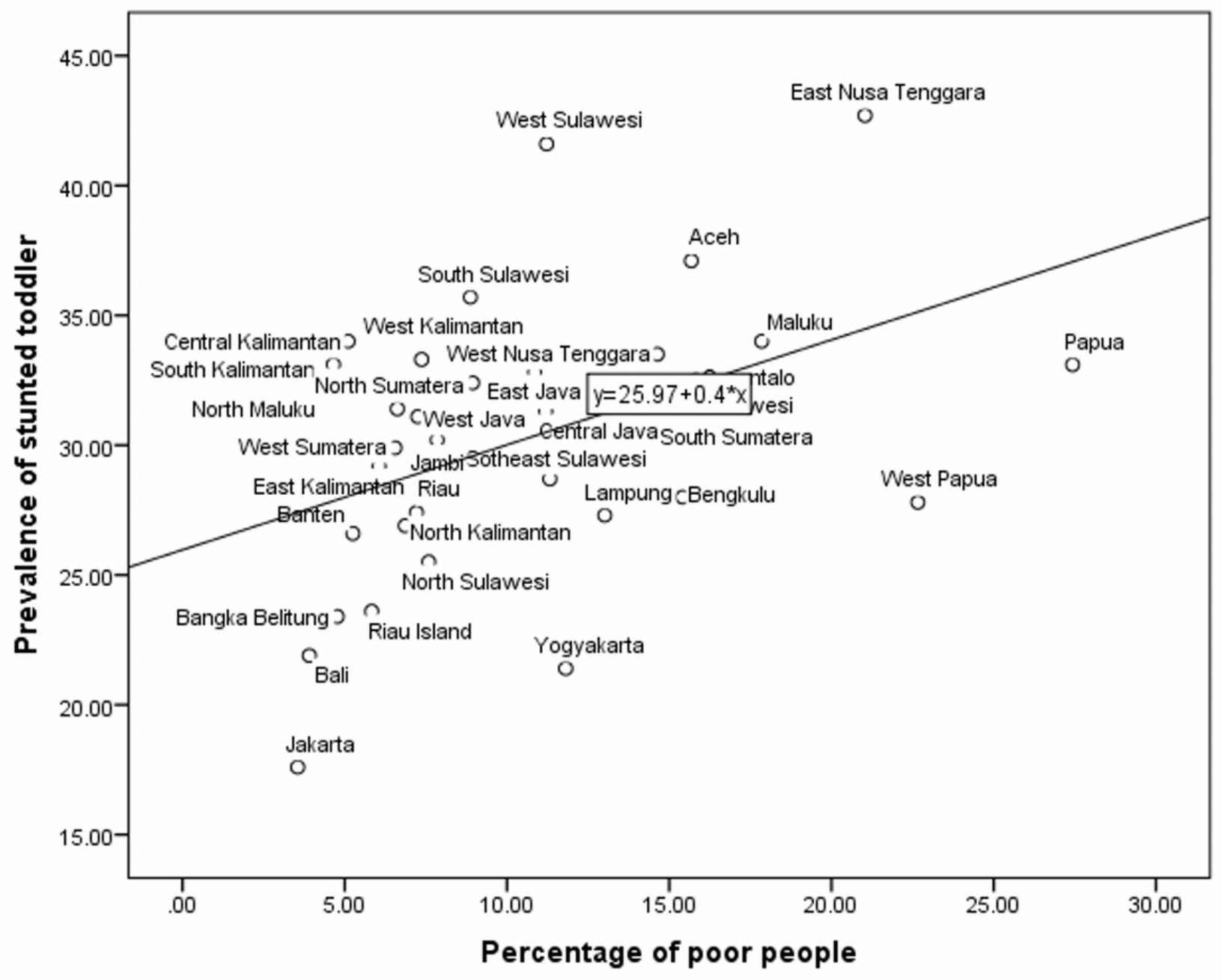

Figure 7

Scatter Plot of the Prevalence of Stunted Toddler and the Percentage of Poor People in Indonesia, 2018 Source: The 2018 Indonesia Basic Health Survey and The 2018 Indonesia Health Profile 